\title{
MEMBANGUN KETAHANAN RELEGIUS ANAK MELALUI ACTIVE PARENTAL INVOLVEMENT
}

\author{
La Husni Buton', Susiati2 ${ }^{2}$, Andi Masniati ${ }^{3}$, Kurniati Tuasalamony", \\ Rahma Satya Masna Hatuwe ${ }^{5}$, Saidna Zulfiqar Bin Tahir6, \\ A. Yusdianti Tenriawali7, Roos Nilawati Marasabessy ${ }^{8}$
}

Universitas Iqra Buru, Namlea, Buru, Maluku, Indonesia kaledupa123@gmail.com

\author{
DOI: $10.33852 /$ jurnalin.v4i1.204

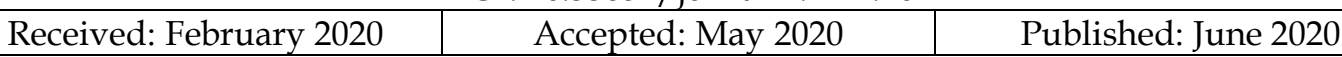

\begin{abstract}
:
The objectives of this study were to 1) determine the behavior of parents in educating children's religiosity; 2) identify children's actions in applying religiosity in society. The location of this research is in Ubung Village, Lilialy District, Buru Regency, because this location is assessed as the role of parents in educating children's religiosity very high and intensively. This research is a qualitative descriptive study. The method in this research is the method of observation with data collection techniques used, namely in-depth interviews, observation, and documentation. The sampling technique used was purposive sampling technique. The results showed 1) parental behavior in educating religiosity in the village of Ubung includes (1) democratic parenting or behavior. In this pattern there are four aspects applied by parents in Ubung Village, namely (a) aspects of affection, (b) aspects of communication, (c) aspects of self-control, (d) aspects of maturity demands; (2) permissive parenting; (3) attachment parenting; (4) authoritarian parenting; (5) helicopter parenting; (6) negligent parenting. 2) As for the children's actions in implementing religiosity in the community in Ubung Village, namely looking happy and happy in their interactions, never learning to control their behavior, having a high sense of care for their surroundings, often less happy, withdrawn, afraid, and less confident When comparing themselves with others, children tend to be afraid of expressing opinions, low self-esteem, and so on.
\end{abstract}

Key words : Child, Religious, Parental Involvement

Abstrak :

Tujuan penelitian ini adalah untuk 1) mengetahui perilaku orangtua dalam mendidik religiusitas anak; 2) mengidentifikasi tindakan anak dalam menerapkan religiusitas dalam masyarakat. Lokasi penelitian ini di Desa Ubung, Kecamatan Lilialy, Kabupaten Buru, karena lokasi ini dinilai peran orangtua dalam mendididk religiusitas anak sangat tinggi dan intensif. Penelitian ini merupakan penelitian deskriptif kualitatif. Metode dalam penelitian ini adalah metode observasi dengan teknik pengumpulan data yang digunakan, yakni wawancara mendalam, observasi, dan dokumentasi. Untuk teknik pengambilan sampel digunakan teknik purposive sampling. Hasil penelitian menunjukkan 1) perilaku orangtua dalam mendidik religiusitas di Desa Ubung meliputi (1) Pola asuh atau perilaku secara demokratis. Dalam pola ini terdapat empat aspek yang diterapkan oleh para orangtua di Desa Ubung, yakni (a) aspek kasih sayang, (b) aspek komunikasi, (c) aspek kontrol diri, (d) aspek tuntutan kedewasaan; (2) pola asuh permisif; (3) pola asuh keterikatan; (4) pola asuh otoriter; (5) pola asuh helikopter; (6) pola asuh lalai. 2) Adapun tindakan anak dalam menerapkan religiusitas dalam masyarakat di Desa Ubung, yakni terlihat bahagia dan gembira dalam setiap pergaulannya, tidak pernah belajar mengontrol perilaku mereka, rasa peduli yang tinggi terhadap sekelilingnya, sering kurang bahagia, menarik diri, takut, dan kurang percaya diri ketika membandingkan diri 
dengan orang lain, anak cenderung penakut dalam mengeluarkan pendapat, self-esteem rendah, dan lain-lain.

Kata Kunci : Anak, Religius, Keterlibatan Orang Tua

\section{PENDAHULUAN}

Pendidikan agama merupakan pendidikan yang utama yang sangat dibutuhkan bagi anak, di mana hal tersebut secara langsung berpengaruh terhadap perilaku dan perkembangan anak. Pendidikan beragama pada anak merupakan awal pembentukan kepribadian, baik atau buruk kepribadian anak tergantung pada orang tua serta lingkungan yang mengasuhnya. Khoiriyah (2017) mengatakan bahwa pendidikan sangat penting untuk membentuk generasi yang siap mengganti tongkat estafet generasi tua dalam rangka membangun masa depan yang cerah. Karena itu pendidikan berperan dalam memberikan kemampuan baru kepada mereka agar mampu mengantisipasi tuntutan masyarakat yang dinamis di masa yang akan datang.

Oleh karena itu, sebagai orang tua mempunyai kewajiban memberikan pendidikan dan bimbingan kepada anak. Hal ini dipertegas oleh Subadar, (2017) bahwa pendidikan merupakan sebuah ikhtiar manusia dengan tujuan membina kepribadiannya sesuai dengan nilai-nilai dan kebudayaan yang terdapat dalam masyarakat.

Mengingat pentingnya pendidikan agama, maka orang tua harus mempunyai pengetahuan yang cukup dalam menegakan pilar-pilar pendidikan agama dalam lingkungan anak entah itu dalam keluarga maupun bermasyarakat. Hal ini secara tegas terdapat dalam sabda Nabi Muhammad SAW yang berbunyi "tidak ada pemberian seorang ayah untuk anaknya yang lebih utama daripada (pendidikan) tata karma yang baik." Hadis tersebut diriwatkan oleh imam At-Tirmidzi dan imam Al-Hakim dari sahabat Amr bin Sa'id bin Ash (Suwaid, 2020).

Selain itu perkembangan teknologi yang sekarang ini merajalela membuat pengaruh besar pada masyarakat. Suatu hal yang tidak dapat dipungkiri bahwa pembangunan di segala bidang, manfaatnya semakin dirasakan oleh semua kalangan. Revolusi informasi menyebabkan dunia terasa semakin kecil, semakin mengglobal dan sebaliknya privacy seakan tidak ada lagi. Berkat revolusi informasi.

Efek dari globalisasi itulah di samping mendatangkan kebahagiaan, juga menimbulkan masalah etis dan kebijakan baru bagimanusia. Efek samping itu ternyata berdampak sosiologis, psikologis dan bahkan teologis. Orangtua harus siap siaga dalam mengontrol anak-anak karena jika kontrol orangtua lemah maka anak akan merasa kurang diperhatikan dan dapat salah jalan dalam bertindak (Xu et al., 2020), declining maternal psychological control would improve relationships between adolescents and their mothers, in turn reducing adolescents' internalizing problems. Contoh dari efek globalisasi adalah banyak anak yang menyalahgunakan teknologi, penggunaan obat-obat terlarang karena pengaruh teman. Nilai-nilai kemasyarakatan yang selama ini dianggap dapat dijadikan sarana penentu dalam berbagai aktivitas, menjadi kehilangan fungsinya (Harahap, 1999). 
Untuk menyikapi fenomena global seperti itu, maka penanaman nilainilai keagamaan dalam jiwa anak secara dini sangat dibutuhkan. Dalam hubungan itu, keluarga diharapkan sebagai lembaga sosial yang paling dasar untuk mewujudkan pembangunan kualitas manusia dalam lembaga ketahanan untuk mewujudkan masyarakat yang bermoral dan berakhlak. Pranata keluarga merupakan titik awal keberangkatan sekaligus sebagai modal awal perjalanan hidup mereka (Harahap, 1999).

Dalam hal ini pendidikan agama merupakan pendidikan dasar yang harus diterapkan kepada anak sejak dini. Hal tersebut mengingat pribadi anak pada usia dini mudah dibentuk menjadi humanism religious karena anak masih banyak berada di bawah pengaruh lingkungan keluarga. Fermadi (2018) menjelaskan bahwa humanism religius sebagai pembentukan etika tersebut dalam perspektif Ibnu Athāeillah terbentuk melalui konsep dasar pemikirannya, dan mempengaruhi peran dan tindakan sosialnya. Di mana etika tersebut berlandaskan nilai humanisme sebagai refleksi dari pemikiranpemikiran sebelumnya. Mengingat fungsi keluarga yang di antaranya adalah pertama, keluarga berfungsi untuk mengatur penyaluran dorongan seks, tidak ada masyarakat yang memperbolehkan seks sebebas-bebasnya antara siapa saja dalam masyarakat. Kedua, reproduksi berupa pengembangan keturunan pun selalu dibatasi dengan aturan yang menempatkan kegiatan ini dalam keluarga. Ketiga, keluarga berfungsi untuk mensosialisasikan anggota baru masyarakat sehingga dapat memerankan apa yang diharapkan darinya. Keempat, keluarga mempunyai fungsi afeksi: keluarga memberikan cinta kasih pada seorang anak. Kelima, keluarga memberikan status pada anak bukan hanya status yang diperoleh seperti status yang terkait dengan jenis kelamin, urutan kelahiran dan hubungan kekerabatan tetapi juga termasuk di dalamnya status yang diperoleh orangtua, yaitu status dalam kelas sosial tertentu. Keenam, keluarga memberikan perlindungan kepada anggotanya, baik perlindungan fisik maupun perlindungan bersifat kejiwaan (Sunarto, 2004).

Hal yang menjadi dasar pertimbangan sehingga peran orang tua dalam mengembangkan religiusitas anak di Desa Ubung menjadi objek penelitian karena Desa Ubung salah satu patokan di Kecamatan Lilialy Kabupaten Buru yang menampakkan sikap atau sifat para orang tua yang sangat tegas terhadap anak-anak mereka untuk tetap menjalankan kewajiban mereka, yakni shalat lima waktu, mengadakan pengajian, dan tingkat solidaritas masyarakat dan para remaja dalam setiap kegiatan keagamaan sangat tinggi.

Berdasarkan deskripsi di atas, penelitian ini bertujuan untuk mengetahui peran orangtua dalam mengembangkan religiusitas anak di Desa Ubung dan mengidentifikasi tindakan anak dalam menerapkan religiusitas dalam masyarakat.

\section{METODE PENELITIAN}

Penelitian ini merupakan penelitian deskriptif kualitatif. Sumber data penelitian ini diambil dari beberapa informan, yakni para orang tua, tokoh masyarakat, anak, dan masyarakat Desa Ubung sedangkan untuk mendapatkan data yang akurat. Teknik pengumpulan datanya dilakukan 
observasi wawancara (interview), dokumentasi. Analis datanya dilakukans ecara sistematis, dimulai dari penyajian data, reduksi data, sampai pada penarikan kesimpulan. Peneliti menggunakan pengecekan keabsahan data menggunakan triangulasi sumber dan metode. Triangulasi digunakan sebagai teknik untuk mengecek keabsahan data. Moleong dalam (Susiati, 2018), triangulasi adalah teknik pemeriksaan keabsahan data yang memanfaatkan sesuatu yang lain dalam membandingkan hasil wawancara terhadap objek penelitian. Tempat yang dipilih sebagai lokasi penelitian adalah Desa Ubung, Kecamatan Lilialy, Kabupaten Buru.

\section{HASIL DAN PEMBAHASAN}

Peranan orang tua dalam membentuk suatu karakter anak sangatlah penting sebab pertama kali anak menerima sosialisasi dari lembaga keluarga. orang tua merupakan cerminan dari anak sehingga anak akan menjadi apa nantinya bergantung dari cara didikan orang tua terutama karakter dalam sikap religiusitas anak dalam bermasyarakat. pendidikan beragama sangat penting diberikan kepada anak karena hal tersebut dapat menjadi bekal seorang anak dalam kehidupan bermasyarakat kelak. Peran orang tua di Desa Ubung dalam memberikan pendidikan religiusitas kepada anak sangat terlihat. Pendidikan religiusitas sangat penting bagi mereka untuk didapatkan oleh anak pada usia dini. Bagi para orang tua, dengan pendidikan agama yang diberikan kepada anak, dapat memberikan pemahaman tentang baik buruk dalam masyarakat sehingga anak-anak tersebut kelak tidak terjerumus dalam hal-hal yang bersifat negatif.

Upaya pendidikan religiusitas di Kabupaten Buru secara umum berkiblat pada dua program unggulan pemerintah daerah Kabupaten Buru, yakni Gerakan Bupolo Maghrib Mengaji (Gelora) dan Gerakan Bupolo Membaca (Gencar). Dengan adanya Gelora, secara tidak langsung memberikan efek positif terhadap kedisiplinan dan kepatuhan kepada seluruh masyarakat tidak terkecuali masyarakat di Desa Ubung. Berikut ini pembahasan secara detail tentang peran orang tua dalam mendidik religiusitas anak dan tindakan anmak dalam menerapkan religiusitas dalam masyarakat.

\section{Pola Perilaku Orang Tua dalam Mendidik Religiusitas Anak}

Peranan orang tua sangatlah penting dalam membentuk kepribadian seorang anak sebab baik dan buruk cara bersosialisasi seorang anak dalam masyarakat bergantung dari cara didikan para orang tua. Dari pola didik orangtua yang diterapkan maka seorang anak dapat merekam apa yang diterima dari orangtua mereka sehingga pola didik yang diberikan orangtua akan mereka terapkan dalam kehidupan sosial masyarakat khusunya pola didik yang bersifat religiusitas.

Salah satu pola didik yang bersifat religiusitas, yaitu pola didik yang diberikan orang tua untuk bekal anak dalam kehidupan bermasyarakat kelak. Pendidikan agama dirasa sangatlah penting dalam kehidupan yang kritis seperti sekarang ini. Dalam mendidik anak, penting untuk memerhatikan pola asuh yang diterapkan oleh orangtua. Setiap orangtua pasti menerapkan caranya sendiri dalam mengasuh buah hati. Hal yang memengaruhi pola asuh 
anak bukan hanya dari sisi pengetahuan, tetapi juga dari pola asuh atau perilaku dari orangtua dalam keluarga. Teori pola asuh yang digunakan dalam penelitian ini adalah teori pola asuh Baumrind. Ada enam bentuk pola asuh atau perilaku orang tua dalam mendidik religiusitas anak di Desa Ubung, yakni

\section{Pola asuh atau didikan demokratis}

Pola asuh atau pola perilaku orang tua mendidik anak secara demokratis adalah cara mendidik anak, di mana orang tua menentukan peraturan-peraturan tetapi dengan memperhatikan keadaan dan kebutuhan anak. Dengan demikian, suatu hak dan kewajiban para orang tua sebagai penanggung jawab yang utama dalam mendidik anaknya Shochib dalam (Fellasari, F; Lestari, 2017). Bentuk pola perilaku orang tua dalam mendidik anak secara demokratis lebih menekankan pada aspek edukatif atau pendidikan dalam membimbing anak sehingga orang tua sering memberikan pengertian, penjelasan, dan penalaran untuk membantu anak mengerti mengapa perilaku tersebut diharapkan.

Para orangtua di Desa Ubung tampak menerapkan pola asuh atau perilaku mereka dalam mendidik secara demokratis sebagai bentuk pengembangan religiusitas anak-anak mereka. Adapun aspek-aspek pola asuh atau perilaku orang tua dalam mendidik secara demokratis, yakni

a. Aspek kasih sayang

Aspek kasih sayang sering diterapkan oleh para orang tua dalam pengembangan religiusitas kepada para anak-anak di Desa Ubung. Aspek kasih sayang ini berbeda-beda di setiap didikan para orang tua. Profesi, sosial ekonomi, dan kepribadian orang tua merupakan faktor yang dapat membedakan pengaktualisasian kasih sayang pada tiaptiap orang tua terhadap anak. Berikut ini hasil wawancara dari narasumber "Katong pung ana-ana itu selalu katong ajar dong bahasa yang bae-bae, kalo dong bahasa galabor langsung katong tagor dong" "Anak-anak kami itu selalu kami ajari bahasa yang santun, kalau mereka menggunakan bahasa yang tidak sopan, kami langsung tegur mereka" (Taufik, 2020). ()

Adapun bentuk aspek kasih sayang para orang tua terhadap pengembangan religiusitas anak-anak di desa Ubung, yakni

1) Mendidik anak berbicara dengan sopan dan santun

Para orang tua di Desa Ubung tidak pernah lengah dengan didikannya terhadap anak-anak mereka salah satunya tata karma dalam berbicara dengan sopan dan santun. Bagi orangtua hal ini penting dalam membentuk karakter anak mereka ketika nanti terjun dalam lingkungan sosial masyarakat. Syariah islam telah memerintahkan kaum muslim untuk senantiasa menghiasi setiap perilakunya dengan akhlak mulia, baik dalam beribadah, bermuamalah dengan orang lain maupun dalam perilaku yang sifatnya pribadi. Dari Abdullah bin Amr sesungguhnya Rasulullah bersabda: "sesungguhnya orang yang terbaik di antara kita adalah orang yang paling baik akhlaknya" 
Di antara akhlak islam yang paling diperintahkan Allah SWT adalah adab berbicara. Rasulullah pernah ditanya tentang perkara yang paling banyak menjadi penyebab masuknya manusia ke neraka, lalu beliau bersabda "perkara itu adalah mulut dan kemaluan". (HR. Riwayat at-Tirmidzi, ia berkata "ini hadist shahih"; Ibnu Hibban dalam kitab shahihnya; al-Bukhari dalam al-Adab al-Mufrad; Ibnu Majah; Ahmad; dan al-Hakim) (Syamsi, 2018).

Beberapa contoh pola asuh atau perilaku orang tua di Desa Ubung dalam mendidik adab berbicara kepada anak-anak mereka seperti membiasakan salam; selalu menyatakan kebenaran atau diam; tidak berdusta, jujur dalam perkataan; bertutur kata dengan baik; berbicara dengan lemah lembut; tidak banyak bicara; berhatihati dan cermat dalam berbicara dan menyampaikan informasi; tidak men-ghibah; tidak mengadu domba; tidak memanggil orang lain dengan panggilan yang tidak disukai; menjauhi berbantah-bantahan; tidak mencaci maki; tidak memotong pembicaraan; menjaga rahasia. Semua pola asuh perilaku orang tua dalam mendidik anak tadi mempunyai dasar baik itu melalui firman Allah SWT maupun dari hadist shahih.

2) Mendidik anak tentang kedisiplinan dan rasa tanggung jawab

Penanaman kedisiplinan dan rasa tanggung jawab harus dimulai sedini mungkin karena berkaitan dengan kebiasaan. Sebaliknya, membiasakan kebiasaan buruk pada anak-anak akan menjadi sebuah karakter yang sulit diubah nantinya. Beberapa contoh para orangtua di Desa Ubung dalam memberikan pola asuh dalam mendidik anak mereka terkait perilaku religiusitas anak, yakni (a) menanamkan aqidah yang kuat. Hal tersebut tampak pada hasil wawancara peneliti ; "Ana-ana salalu katong ajar dong deng nasehat-nasehat tentang nabi pung sifat-sifat, katong ajar dong musti tanggung jawab, deng katong jua ajar dong supaya hormat par orang tatua" "Anak-anak selalu kami bekali dengan petuah-petuah tentang sifat-sifat Nabi, kami mengajari tentang pentingnya menumbuhkan sikap tanggung jawab, menghormati orang tua serta menhargai waktu" (Sardi, 2020).

Dari hasil wawancara peneliti dengan para orang tua disimpulkan bahwa aqidah yang kokoh akan menanamkan keyakinan bahwa sebagai hamba Allah SWT kita wajib mengikuti aturan-Nya. Salah satu aturan yang dimaksud adalah sikap bertanggung jawab. Melalui pendekatan ini, akan tertanam sikap keikhlasan melaksanakan akhlak tersebut semata-mata karena Allah SWT. Sedini mungkin anak harus mulai belajar untuk melaksanakan kebaikan-kebaikan seperti kedisiplinan dan rasa tanggung jawab bukan untuk mengharapkan imbalan materi atau pujian orang lain. Sikap ini juga akan memberi imunitas yang tinggi manakala ia terancam oleh lingkungan yang kurang baik; (b) mengajarkan keteladanan Rasulullah SAW. Sebagai seorang muslim kita sudah sering mendengar keteladanan-keteladan Rasulullah SAW misalnya 
dalam acara Isra' Mi'raj yang rutin dilaksanakan tiap tahun oleh warga islam di seluruh dunia, tak terkecuali masyarakat desa Ubung. Hal ini, berimplikasi pula pada perilaku para orangtua dalam mendidik anak dengan berpedoman pada keteladanan Rasulullah SAW; (c) mengajarkan tentang disiplin waktu. Bagi para orangtua mengajarkan kedisiplilan kepada anak sangatlah penting mulai dari shalat lima waktu hingga kedisiplinan dalam rutinitas di rumah dan di sekolah. Hal tersebut tampak dalam pola asuh para orangtua di Desa Ubung. Para anak-anak dibiasakan melaksanakan shalat lima waktu tepat waktu. Selain itu, rutinitas atau kegiatan di rumah seperti membantu orangtua dan waktu belajar pun diperhatikan oleh para orangtua. Bagi mereka, hal-hal tersebut harus terus dibiasakan sehingga akan muncul dengan sendirinya kesadaran dalam diri anak-anak mereka tentang pentingnya kedisiplinan.

\section{b. Aspek Komunikasi}

Komunikasi adalah interaksi tatap muka antara dua orang atau sekelompok orang, di mana pengirim dapat menyampaikan pesan secara langsung dan penerima pesan dapat menyampaikan pesan secara langsung pula. Aspek komunikasi sangat penting diterapkan oleh para orang tua dalam pengembangan religiusitas anak karena komunikasi merupakan salah satu unsur terpenting dalam hidup manusia. Adapun hasil wawancara dari orangtua di Desa Ubung adalah "kami sebagai orangtua selalu menasehati anak-anak kami untuk selalu berempati sama orang lain, selain itu kami selalu panggil mereka untuk berbincang-bincang sambil minum kopi di depan rumah"(Rahman, 2020).

Beberapa aspek komunikasi yang diterapkan oleh para orang tua dalam mendidik religiusitas anak di Desa Ubung adalah

1) Keterbukaan

Keterbukaan yang dimaksud adalah kesediaan untuk untuk mengakui perasaan dan pikiran sebagai milik setiap orang dan harus bertanggung jawab atasnya. Sikap keterbukaan tampak pula pada setiap orangtua di Desa Ubung. Mereka selalu mengajak sang anak berbincang-bincang baik itu ketika anak pulang dari sekolah, saat makan bersama, atau kala mereka santai. Hal ini dilakukan agar dalam diri sang anak dapat terbentuk sikap membuka diri, kejujuran, dan sikap terbuka (mengakui bahwa perasaan dan pikiran yang dilontarkan adalah milik kita dan kita bertanggung jawab atasnya).

2) Empati (emphaty)

Empati merupakan kemampuan seseorang untuk mengetahui setiap hal yang dihadapi atau dialami oleh orang lain, pada suatu masa tertentu, dari sudut pandang orang lain, dan melalui kacamata orang lain. Sikap ini terlihat pula pada anak-anak di Desa Ubung. Hal ini karena didikan dari para orangtua. Mereka mengajarkan perilaku empati pada anak-anak dengan tujuan agar kala anak-anak 
mereka lebih aktif bersosialisasi di masyarakat mampu memahami motivasi dan pengalaman, perasaan, dan sikap orang lain. Selain itu, dengan sikap empati ini para anak dapat menahan godaan untuk menilai, menafsirkan, mengevaluasi, dan mengkritik. Sikap empati ini pula membawa para anak untuk lebih banyak mengenal orang di sekelilingnya (pengalaman, keinginan, kemampuan, dan ketakutan) sehingga mereka mampu melihat dan merasakan hal-hal yang dialami oleh orang disekeliling mereka.

3) Dukungan (supportiveness)

Dukungan yang dimaksud di sini adalah suatu perilaku atau sikap yang memperlihatkan perasaan mendukung terhadap suatu hal. Para orangtua di Desa Ubung selalu memberikan nasihat kepada anak-anak mereka tentang pentingnya menerapkan sikap suportif dalam diri. Sikap mendukung yang sering diajarkan dan dijelaskan oleh para orangtua misalnya dalam diri manusia memiliki sikap spontanitas dan profesionalisme. Sikap spontanitas atau terus terang dapat menciptakan suasana mendukung. Dari hal ini, dapat kita simpulkan bahwa suatu tindakan spontanitas dapat melahirkan sikap yang negatif dan positif bergantung dari stimulus yang didapatkan si anak. Pemahaman sikap spontanitas ini memberikan tentang gambaran kepada si anak bahwa jika kita dihadapkan dengan sesuatu yang baik ataupun buruk bersikaplah dengan hati-hati atau tenang. Sikap profesionalisme tampak pula pada didikan para orangtua di Desa Ubung. Anak-anak diajarkan betapa pentingnya menumbuhkan sikap profesionalisme dalam diri, karena sikap profesional merupakan sikap keterbukaan serta bersedia mendengar pandangan orang lain baik itu bertentangan atau searah serta bersedia mengubah posisi jika keadaan mengharuskan. Jika seseorang bertindak secara professional dengan pikiran terbuka, dengan kesadaran penuh bahwa orang lain mungkin saja keliru, dan dengan kesediaan untuk mengubah sikap dan pendapatnya maka orang tersebut dapat didorong atau didukung.

4) Sikap positif (positiveness)

Para orangtua dalam menumbuhkan perilaku positif pada anak terlihat di Desa Ubung. Sikap positif yang dimaksud adalah sikap peduli kepada sesama. Sikap peduli tersebut adalah peduli kepada seluruh ciptaan Allah SWT, yakni kepada sesama manusia, tumbuhan, alam, dan binatang. Penerapan sikap ini secara langsung diterapkan oleh para orangtua melalui kegiatan keseharian mereka. Sehingga secara tidak langsung anak-anak mereka melihat dan mendapat pelajarang dari sikap orangtua mereka.

5) Kesetaraan (equality)

Dalam komunikasi, sikap equality (kesetaraan) sangat diharapkan. Kesetaraan tidak berarti mengharuskan seseorang menerima dan menyetujui begitu saja semua perilaku verbal dan nonverbal pihak lain. Kesetaraan berarti menerima pihak lain sebagai lawan bicara 
atau kesetaraan meminta seseorang untuk memberikan penghargaan positif tidak bersyarat kepada orang lain.

c. Aspek kontrol diri

Kontrol diri merupakan kemampuan untuk membimbing, mengatur, menyusun, dan mengarahkan bentuk perilaku yang dapat membawa ke arah konsekuensi positif. Selain itu, kontrol diri adalah salah satu potensi yang dapat dikembangkan dan digunakan individu selama proses kehidupan termasuk dalam menghadapi keadaan atau masalah yang terjadi di lingkungan sekitarnya.

Kontrol diri juga dapat diartikan sebagai salah satu kompetensi pribadi yang perlu dimiliki oleh setiap individu. Perilaku yang baik, konstruktif, serta keharmonisan dengan orang lain dipengaruhi oleh kemampuan individu untuk mengendalikan dirinya. Sekuat apapun stimulus dan penguat eksternal, perilaku individu masih bisa diubah melalui proses kontrol diri.

Penerapan kontrol diri tersebut diterapkan oleh para orangtua di Desa Ubung dalam pengembangan sikap religiusitas anak-anak mereka. Kontrol diri tersebut berkaitan dengan bagaimana seorang anak mengendalikan emosi serta dorongan-dorongan dari dalam diri si anak. Terdapat tiga aspek kontrol diri pada anak-anak di Desa Ubung, yakni ;

1) Behavioral control (kontrol perilaku)

Para orang tua di Desa Ubung sangat aktif dalam melihat perkembangan anak-anak mereka, salah satunya mengontrol perilaku sang anak. Perilaku atau sikap anak-anak dominan masih labil, artinya mereka masih kurang stabil dalam mengelola atau mengontrol perilaku mereka. Mereka dominan belum mengerti jika melakukan suatu hal akan berakibat apa. Sehingga peran orang tua harus selalu ada dalam tiap tindakan para anak. Namun, dengan memperhatikan kenyamanan si anak, para orang tua di Desa Ubung sering menasehati anak-anak mereka agar selalu berhati-hati dalam bertindak. Seperti mengajarkan anak untuk tidak berperilaku sombong kepada sesama. Hal tersebut dipertegas dalam QS.Al-Isra: 37 yang berbunyi "Dan janganlah kamu berjalan di muka bumi dengan sombong..."

2) Cognitif control (kontrol kognitif)

Kontrol kognitif bermakna sebagai kemampuan individu dalam mengendalikan diri untuk mengolah informasi yang tidak diinginkan dengan cara menilai, menginterpretasi, dan menghubungkan suatu kejadian ke dalam suatu kerangka kognitif sebagai adaptasi psikologi untuk mengurangi tekanan yang dihadapi.

Penerapan kontrol kognitif ini terlihat dala pola asuh atau perilaku orang tua dalam mendidik anak mereka. Anak-anak diajarkan cara-cara mengelola, menilai, mengevaluasi informasi- 
informasi yang di dengar, jika mendapat atau mendengar informasi yang mengarah pada hal negatif atau positif harap cari sumbernya apakah fakta atau sebatas hoaks (berita bohong). Hal tersebut dipertegas pula dalam QS. Al-Hujurat ayat 10 yang menjelaskan bahwa setiap muslim itu bersaudara dengan muslim lainnya. Persaudaraan itu diibaratkan dengan satu tubuh apabila salah satu tubuh sakit maka yang lain juga merasakannya. Bahkan apabila perselisihan tidak terelakkan, maka tidak diperbolehkan sesame muslim lebih dari 3 hari.

3) Decisional control (mengontrol keputusan)

Decisional control merupakan kemampuan individu dalam mengendalikan diri untuk memilih suatu tindakan berdasarkan pada sesuatu yang disetujui atau diyakini. Decisional control berfungsi menentukan pilihan, baik dengan adanya suatu kesempatan maupun kebebasan pada diri individu untuk memilih berbagai kemungkinan tindakan. Anak-anak di Desa Ubung dibekali oleh sikap atau perilaku cara mengontrol keputusan. Hal ini dilakukan agar anak-anak dapat cekatan dalam mengolah, mengelolah, mengontrol pilihan yang akan mereka ambil. Cara mengontrol keputusan ini terdapat dalam QS. Al-Imran: 159 yang. penafsirannya bahwa islam menggariskan kepada pemimpin untuk mengambil keputusan secara bermusyawarah, lemah lembut, bersiap, dan memaafkan. Apabila keputusan telah diambil maka harus patuh dan komitmen dalam menjalankannya.

d. Aspek tuntutan kedewasaan

Pola asuh demokratis lebih mengedepankan orang tua dalam memberikan aturan dan pedoman. Orang tua harus selalu mendengarkan setiap pendapat atau pertanyaan anak dan bersikap responsif terhadap anak. Orang tua suka memberi dukungan, mudah memaafkan, tidak menyalahkan anak bila si anak melakukan kesalahan atau kegaglan, dan tidak terlalu membatasi anak.

Aspek tuntutan kedewasaan yang pertama adalah kita sebagai manusia harus memiliki sikap kedewasan dalam bertuhan. Artinya, kita harus percaya dan berbakti kepada Allah SWT.

Selain itu, ketika seorang anak mengalami kegagalan atau ada kesalahan yang dilakukan. Namun, orang tua tidak secara langsung memarahi tetapi mereka menginterogasi sang anak sehingga sang anak menceritakan secara detil penyebab permasalahan yang dialaminya. Aspek ini dominan terlihat pada para orang tua yang berprofesi sebagai guru, ustadz, dan pekerja kantoran. 


\section{Pola asuh atau Didikan Permisif}

Orangtua dengan pola asuh yang permisif dicirikan sedikit memberikan tuntutan dan harapan pada anak. Orangtua juga cenderung memanjakan buah hati, menghindari dialog dengan anak sehingga anak jadi sulit mandiri dan biasanya sulit memimpin.

Penerapan pola asuh permisif di Desa Ubung oleh para orang tua masuk pada tataran sedang. Para orang tua menerapkan didikan dengan mengikuti kemauan sang anak tetapi mereka imbangi dengan masukanmasukan atau kritikan jika langkah sang anak ke arah yang negatif. Dengan kata lain, apapun yang dilakukan sang anak masih diperhatikan oleh para orang tua mereka.

a. Pola asuh atau didikan keterikatan

Pola asuh ini lebih berfokus pada anak. Orangtua berusaha membuat anak terjamin dan terasa aman. Orangtua sering menciptakan komunikasi dengan banyak melakukan sentuhan fisik pada anak seperti menggendong, menyentuh, memeluk, bahkan tidur bersama dengan anak.

Penerapan pola asuh atau perilaku orangtua dalam mendidik para anak dengan pola asuh keterikatan terlihat pula di Desa Ubung. Para orangtua membiasakan melakukan sentuhan fisik seperti ketika anak merasakan kegagalan maka dominan para orangtua memeluk sang anak dan menenangkannya. Selain itu, pola asuh keterikatan ini terlihat pula ketika sang anak punya masalah dengan lingkungannya, orangtua langsung menjadi penengah.

b. Pola asuh atau didikan otoriter

Pola asuh otoriter biasanya memberikan anak aturan yang ketat. Bila anak tidak mematuhinya akan mendapat hukuman. Pemberian dukungan tidak sama dengan tuntutan tinggi yang diberikan oleh anak-anak. Orangtua juga sangat mendominasi kehidupan anak. Anak yang dididik dengan pola asuh otoriter biasanya memang cenderung mudah diatur dan penurut. Namun, anak cenderung tidak bahagia, sulit mengambil keputusan sendiri, dan takut mencoba.

Dengan perkembangan zaman yang serba modern, banyak orangtua di Desa Ubung yang menerapkan pola asuh ketat. Pola asuh ketat ini dominan diterapkan oleh para orangtua yang berprofesi sebagai tenaga pendidik. Para orang tua sangat merasa khawatir dengan pergaulan para remaja sekarang baik itu melalui sosial media maupun pergaulan secara langsung. Efek dari kekhawatiran ini banyak para orang tua sangat selektif dalam pergaulan sang anak. Seperti, para orang tua mengawasi sang anak agar tidak melalaikan shalat lima waktu dan menerapkan disiplin waktu sang anak terkait waktu kebersamaan sang anak dengan teman sebaya.

c. Pola asuh atau didikan helikopter

Orang tua dengan cara pola asuh helikopter sering mengatur setiap aspek dalam kehidupan anaknya, seperti makanan yang dikonsumsi setiap hari, lingkungan pertemanan, bahkan waktu luang 
yang dilakukan anak. Mereka selalu ingin membantu kesulitan yang dialami anak. Sayangnya, dengan cara mengasuh anak seperti ini, orangtua menjadi kurang percaya terhadap anak.

Penerapan perilaku asuh orangtua dengan pola helikopter ini terlihat pada beberapa orangtua di Desa Ubung. Hal ini dilakukan karena adanya masalah yang pernah dihadapi oleh sang anak seperti sang anak pernah mengalami masalah di lingkungan masyarakat, sang anak pernah terjerumus dalam kenakalan remaja. Para orangtua yang menerapkan pola asuh ini, sebelumnya melalui tahap pola asuh permisif tetapi malah menjerumuskan sang anak pada hal-hal negatif sehingga para orangtua tersebut mengubah pola perilaku mereka dalam mendidik anak-anak mereka ke pola asuh helikopter.

d. Pola asuh atau didikan lalai

Biasanya cara pola asuh anak ini disirikan orangtua yang terlalu membebaskan anak untuk berbuat semau mereka dan orangtua tidak melibatkan apa pun yang terkait dengan anak. Orangtua tidak responsif, jarang menuntut, dan jarang berkomunikasi dengan anak.

Orangtua hanya memastikan jika anak mereka tercukupi kebutuhan dasarnya. Sementara, mereka tidak memerhatikan kebutuhan emosional anak. Anak yang diasuh seperti ini, biasanya tidak memiliki kontrol diri dan kurang percaya diri.

Pola asuh ini terlihat pada sebagian orangtua di Desa Ubung yang berprofesi pekerja kantoran. Banyak orangtua yang mementingkan kepentingan pekerjaannya dibandingkan dengan pemenuhan kebutuhan emosional sang anak sehingga berimbas pada perilaku sang anak yang tertutup.

\section{Tindakan Anak dalam Menerapkan Religiusitas di Masyarakat}

Pola asuh atau perilaku orangtua dalam mendidik anak terkait pengembangan religiusitas sang anak memiliki korelasi dengan tindakan atau perilaku anak di masyarakat. Beberapa perilaku atau tindakan sang anak sebagai berikut

1. Tindakan anak dengan pola asuh atau didikan demokratis

Adapun tindakan atau perilaku religiusitas anak di Desa Ubung dengan menggunakan pola asuh demokratis adalah terlihat bahagia dan gembira dalam setiap pergaulannya, memiliki kepercayaan diri, aktif dalam mengungkapkan pendapat, dan dapat mengontrol emosi, berjiwa petualang atau eksploratif, mempunyai rasa ingin tahu yang tinggi, achievement-oriented tetapi bertindak sesuai kemampuan yang dimiliki, pintar menyesuaikan dalam bersosialisasi dengan masyarakat, membangun hubungan yang bersahabat dengan lingkungan sosialnya, Kooperatif, dapat membawa diri dengan baik, mudah dalam mengelola stres yang dialami, mempunyai sifat sabar, rendah hati, dan tata karma dalam bertindak

2. Tindakan anak dengan pola asuh atau didikan permisif

Adapun tindakan atau perilaku religiusitas anak di Desa Ubung dengan menggunakan pola asuh permisif adalah tidak pernah belajar 
mengontrol perilaku mereka, kekurangan kepercayaan diri, berperilaku impulsif dan agresif, cenderung sesuka hati, melakukan eksplorasi sebebasnya, memiliki kontrol diri dan emosi yang rendah, kurang berprestasi, kurang pandai dalam mengambil keputusan, kurang cekatan dalam mengatur waktu atau kebiasaan

3. Tindakan anak dengan pola asuh atau didikan keterikatan

Adapun tindakan atau perilaku religiusitas anak di Desa Ubung dengan menggunakan pola asuh keterikatan adalah memiliki tenggang rasa yang tinggi kepada sesama, rasa peduli yang tinggi terhadap sekelilingnya, aktif mengajak teman-temannya dalam mengerjakan kebaikan

4. Tindakan anak dengan pola asuh atau didikan otoriter

Adapun tindakan atau perilaku religiusitas anak di Desa Ubung dengan menggunakan pola asuh otoriter adalah, bertindak tidak sesuai dengan yang diinginkannya, terlihat kurang memiliki tujuan, sering kurang bahagia, menarik diri, takut, dan kurang percaya diri ketika membandingkan diri dengan orang lain

5. Tindakan anak dengan pola perilaku helikopter

Adapun tindakan atau perilaku religiusitas anak di Desa Ubung dengan menggunakan pola asuh helikopter adalah anak cenderung penakut dalam mengeluarkan pendapat, muncul kedisiplinan dalam diri sang anak

6. Tindakan anak dengan pola asuh atau didikan lalai

Adapun tindakan atau perilaku religiusitas anak di Desa Ubung dengan menggunakan pola asuh lalai adalah anak merasa hal-hal lebih penting bagi orang tua daripada anak sendiri, kekurangan ikatan dengan orang tua, secara kognitif, emosi, keterampilan sosial, dan perilaku kurang berkembang, memiliki kelemahan dalam mengontrol diri, Self-esteem rendah, merasa terasingkan atau terabaikan dalam keluarga, pada masa remaja, mungkin anak menunjukkan perilaku kenakalan remaja.

Berangkat dari hal tersebut di atas, dapat dipahami bahwa pola asuh orang tua pada umumnya sangat mempengaruhi kepribadian seorang anak. Baumrind dalam (Fellasari, F; Lestari, 2017) mendefinisikan pola asu sebagai pola sikap atau perlakuan orangtua terhadap anak yang masing-masing mempunyai pengaruh tersendiri terhadap perilaku anak antara lain terhadap kompetensi emosional, social, dan intelektual. Menurut (Sary, 2018), parenting is a pattern of interaction between parents and children or can be said to be the attitude or behavior of parents when interacting with children, including how to apply the rules, teach values or norms, give attention and love and show good attitudes and behaviors so that they become role models for their children.

Ada enam bentuk pola asuh menurut Baumrind, yakni; Pola asuh demokratis, Pola asuh permisif, Pola asuh keterikatan, Pola asuh otoriter, Pola ashu helicopter, Pola asuh lalai, (Subadar, 2017). Pola asuh yang baik akan memberikan dampak pskilogis, khususnya terhadap perilaku keberagamaan (relegius) yang besar bagi anak, begitu juga sebaliknya.

Perilaku dalam hal ini dipahami sebagai tindakan atau aktivitas dari manusia itu sendiri yang mempunyai bentangan sangat luas antara lain 
berjalan, berbicara, menangis, tertawa, bekerja, kuliah, menulis, dan membaca. Skinner dalam (Aslan, 2017), perilaku terbagi menjadi dua jenis, yakni 1) perilaku alami (innate behavior), yaitu perilaku yang dibawa sejak organisme dilahirkan, yakni berupa reflex-refleks dan insting-insting; 2) perilaku operan, yakni perilaku yang dibentuk, dipelajari, dan dapat dikendalikan dan diatur oleh pusat kesadaran atau otak.

Religiusitas (perilaku religi) adalah sikap hati nurani, batin dan pikiran manusia yang selalu diarahkan kepada perbuatan baik, kasih sayang, kebenaran dan keadilan. Religiusitas setingkat lebih atas daripada sekedar beragama. Religiusitas dapat diperoleh dari pengalaman hidup. Dari pengalaman hidup itulah manusia akan lebih yakin dan lebih mendalami agama yang ia anut. Tidak itu saja manusia akan lebih menghayati bagaimana hidup bermasyarakat dengan lebih baik.

Dalam menanamkan religiusitas ini, tidak semua usia anak dapat menerimanya atau mengerti tentang religiositas, maka dari itu diperlukan batasan umur yang sekiranya anak sudah mengerti tentang agama yang di anutnya. Biasanya anak sudah mengerti pada usia saat mereka menginjak usia 13 sampai 17 tahun. Di usia tersebut anak akan lebih bisa menerima apa yang diajarkan orangtua mereka, termasuk perilaku bereligiusitas. Karena batasan pada usia tersebut anak sudah mengenal pendidikan yang bersifat multikultural, ada empat hal yang penting yang diajarkan kepada anak usia dini untuk menanamkan watak multicultural di antaranya; pendidikan tentang "self" atau penghargaan tentang dirinya sendiri, social skill atau penghargaan dan empati kepada orang lain, emotion skill atau kemampuan positif menyikapi perbedaan dan kreatifitas (Husein, 2008).

\section{KESIMPULAN}

Berdasarkan hasil penelitian, dapat disimpulkan bahwa perilaku orangtua dalam mendidik religiusitas di Desa Ubung adalah 1) Pola asuh atau perilaku secara demokratis. Dalam pola ini terdapat empat aspek yang diterapkan oleh para orangtua di Desa Ubung, yakni a) aspek kasih sayang meliputi mendidik anak berbicara dengan sopan dan santun, kedisiplinan, serta rasa tanggung jawab; b) aspek komunikasi meliputi keterbukaan, empati, dukungan, sikap positif, dan kesetaraan; c) aspek kontrol diri meliputi behavioral control, cognitive control, decisional control; d) aspek tuntutan kedewasaan. 2) pola asuh permisif. Penerapan pola asuh permisif di Desa Ubung berada pada tataran sedang; 3) pola asuh keterikatan di Desa Ubung dominan para orangtua membiasakan sentuhan fisik kepada sang anak; 4) pola asuh otoriter di Desa Ubung dominan diterapkan oleh para orangtua yang berprofesi sebagai tenaga pendidik (guru, dosen, dan ustadz); 5) pola asuh helicopter diterapkan oleh para orangtua terhadap anak-anak yang mengalami kondisi emosi yang tidak terkendali; 6) pola asuh lalai dominan diterapkan oleh para orangtua yang berprofesi pekerja kantoran.

Adapun tindakan anak dalam menerapkan religiusitas dalam masyarakat di Desa Ubung, yakni terlihat bahagia dan gembira dalam setiap pergaulannya, tidak pernah belajar mengontrol perilaku mereka, rasa peduli yang tinggi terhadap sekelilingnya, sering kurang bahagia, menarik diri, takut, 
dan kurang percaya diri ketika membandingkan diri dengan orang lain, anak cenderung penakut dalam mengeluarkan pendapat, self-esteem rendah, dan lain-lain.

\section{UCAPAN TERIMA KASIH}

Penulis mengucapkan terima kasih kepada Jurnal ISLAM NUSANTARA atas diterimanya artikel ini untuk dipublikasi. Selanjutnya, penulis juga mengucapkan terima kasih kepada Kemenristekdikti dan LLDikti Wilayah XII Maluku dan Maluku Utara atas kepercayaannya memberikan dana hibah terhadap penelitian ini.

\section{DAFTAR PUSTAKA}

Aslan. (2017). Nilai-nilai Kearifan Lokal Dalam Budaya Pantang Larang Suku Melayu Sambas. Jurnal Ilmu Usbuluddin, 16(1), 11-20. https://doi.org/10.18592/jiiu.v16i1.1438

Fellasari, F; Lestari, Y. I. (2017). Hubungan antara Pola Asuh Orangtua dengan Kematangan Emosi Remaja. Psikologi, 12(2), 84-90. https://doi.org/http://dx.doi.org/10.24014/jp.v12i2.3234

Fermadi, B. (2018). Humanisme Sebagai Dasar Pembentukan Etika Religius: Dalam Perspektif Ibnu Atha'illah Al- Sakandari. Jurnal Islam Nusantara, 2(1), 72-89. https:// doi.org/10.33852/jurnalin.v2i1.71

Harahap, H. S. (1999). Islam: Konsep dan Implentasi Pemberdayaan. Yogyakarta: Wacana Yogyakarta.

Husein, F. (2008). Resonansi Dialog Agama ddan Budaya Center for Regious dan Cross, Cultural Studies (CRCS). Yogyakarta: Universitas Gadjah Mada.

Khoiriyah, R. (2017). Revitalisasi Pendidikan Islam dalam Perspektif Kiayi Hasyim Asyari. Jurnal Islam Nusantara, 1(2), 159-170. https://doi.org/10.33852/jurnalin.v1i2.33

Sary, Y. N. E. (2018). Relationship of Parenting with Child Interpersonal Intelligence in Wonokerto Village, Lumajang Regency. Obsesi, 2(2), 137142. https://doi.org/https://doi.org/10.31004/obsesi.v2i2.93

Subadar. (2017). Membangun Budaya Religius Melalui Kegiatan Supervisi di Madrasah. Jurnal Islam Nusantara, 1(2), 193-204. https://doi.org/https://doi.org/10.33852/jurnalin.v1i2.35

Sunarto, K. (2004). Pengantar Sosiologi. Jakarta: Mizan.

Susiati, S. (2018). Homonim bahasa kepulauan tukang besi dialek kaledupa di kabupaten wakatobi [the homonymon of tukang besi island languange in kaledupa dialect at wakatobi regency]. Totobuang, 6(1), 109, 123.

Suwaid, M. N. (2020). Prophetic Parenting: Cara Nabi Mendidik Anak. Jakarta: ProLi Media.

Syamsi, H. (2018). Modern Islamic Parenting. Jakarta: Aisar.

Xu, Gangmin; Bullock, Amanda; Yang, Panpan; Liu, Junsheng. (2020). Psychological Control and Internalizing Problems: The Mediating Role of Mother-Child Relationship Quality. Parenting, 1-10. https://doi.org/https://doi.org/10.1080/15295192.2020.1831295 